\title{
The black lion tamarin Leontopithecus chrysopygus - its conservation and management
}

\author{
Ana Carolina Mamede-Costa and Nivar Gobbi
}

The black lion tamarin Leontopithecus chrysopygus originally occurred throughout a large part of the Atlantic forest in the west of the state of São Paulo, Brazil. Today, however, it is restricted to a few isolated forest fragments as a result of deforestation caused by cattle ranching, and urban and agricultural expansion, especially in this century. One of its last strongholds is a small gallery forest at Lençóis Paulista in the west-central part of the state. The authors report on a long-term study of this small and isolated population, aimed particularly at providing a basis for the intensive management and conservation of the species and its habitat.

\section{Introduction}

All four species of lion tamarins are threatened with extinction as a result of the widespread and almost total destruction of the Atlantic forest: c. 7 per cent remains of the forests that once covered more than 1,200,000 $\mathrm{sq} \mathrm{km}$ of eastern and southern Brazil. All 18 of the Atlantic forest's endemic primates were ranked as Critically Endangered, Endangered or Vulnerable in the World Conservation Union's most recent evaluation of threatened species (IUCN, 1996), and with about 1000 individuals remaining in just six isolated localities (Valladares-Pádua et al., 1994), the black lion tamarin Leontopithecus chrysopygus was ranked as Critically Endangered.

Endemic to the state of São Paulo, the black lion tamarin was originally found along the northern margin of the Rio Paranapanema, east of the Rio Paraná and south of the Rio Tietê. It was first discovered by J. Natterer, who collected the type series in 1822 from Ipanema (now Varnhagem), near Sorocaba, São Paulo, and resulted in the description of the species by Johann Christian Mikan in 1823. In 1902 Ernst Garbe, Director of the Zoology Museum, São Paulo, collected three specimens from Vitória, municipality of Botucatu, São
Paulo, and in 1905 O. Hume donated a specimen to the museum, collected from Bauru (Coimbra-Filho, 1970, 1976). These were the only records for the species until Adelmar F. Coimbra-Filho discovered two specimens mounted by a taxidermist in the town of Presidente Wenceslau in 1970 . They were reported to have been obtained from a forest patch on a nearby ranch, the Fazenda Kitayama, which, however, had already been destroyed. Coimbra-Filho subsequently carried out expeditions to the municipalities of Presidente Epitácio and Teodoro Sampaio and, in May 1970, observed three individuals in the Morro do Diabo State Reserve, on the banks of the Rio Paranapanema, in the far west of the state of São Paulo, the first report of the species after 75 years.

For some years this was thought to be the only surviving population, but in 1976 Olav Mielke, an entomologist from the Federal University of Paraná, observed and photographed $L$. chrysopygus in an isolated forest patch in the Fazenda Paraíso, municipality of Gália, São Paulo (Coimbra-Filho, 1976). He alerted Coimbra-Filho, and in that same year the forest was decreed a State Reserve of 2179 ha, and later, in 1987, the Caetetus State Ecological Station. 


\section{Forest destruction in São Paulo}

The destruction of the forests of the region known previously as the Alta Sorocabana in the western São Paulo, started in the 1920s, for timber extraction and coffee plantations and later (from 1929-30) for cotton and peanut farming. Today the predominant industry in the region is cattle ranching. The timber industry thrived from the 1930s; the town of Presidente Prudente, for example, registering 36 sawmills in 1935 . The timber was transported by the Sorocaba railway line (now abandoned), which reached the town of Presidente Prudente in 1917 and passed through the Morro do Diabo State Reserve. The decline of the forests is detectable from the decline of the timber industry from 1960. Three forest reserves were decreed in the area in 1941-42: Morro do Diabo $(37,156$ ha), Lagoa São Paulo in the north (13,343 ha) and the immense Reserva do Pontal ( 246,840 ha). The destruction of the forests continued, however, unabated. In 1956 decrees by the State Governor, Jânio Quadros, along with reinforcement for the policing of the area, slowed down the destruction, but the decrees were revoked 10 years later and this resulted in the almost total destruction of all the forests except those in the Morro do Diabo State Reserve, albeit extensively logged, hunted and degraded (Coimbra-Filho, 1976; Leite, 1979). It is important to emphasize that the destruction of the São Paulo Atlantic forest is recent. In 1900 approximately 70 per cent of the forests were intact; by 1920 the figure was reduced to 45 per cent, by 1950 to 29 per cent and by 1973 to only 8 per cent (Leite, 1979). The construction of the Primavera hydroelectric dam, Rio Paraná, to be completed in 1998, will flood what was left of the Lagoa São Paulo Reserve, and the Rosana dam, completed in 1986, flooded remnant forests along the Rio Paranapanema, along with 3000 ha of the Morro do Diabo State Reserve. The Morro do Diabo State Reserve suffered from the lack of supplementary legislation for its protection, the initial decree simply declaring the area government land and as a reserve for the protection of the fauna and flora (Leite, 1979). A history of the destruction of the forests and the causes in the Pontal region is given by Dean (1995).

\section{Protection for the black lion tamarin}

As Coimbra-Filho and Mittermeier (1977) pointed out, the future of $L$. chrysopygus in the wild depends almost entirely on protecting the Morro do Diabo State Reserve. It was only in 1983-85, with the construction of the Rosana hydroelectric dam, however, with the imminent inundation of 3000 ha (10 per cent) of its forests, that consideration was given to the effective protection of the reserve. On the initiative of a number of institutions - including the São Paulo Electricity Company (CESP), the Brazilian Foundation for Conservation of Nature (FBCN), the São Paulo Forestry Institute (IF/SP), the Rio de Janeiro Primate Centre (CPRJ), the World Wildlife Fund-US Primate Program (see Mittermeier, 1982), and the Federal University of Minas Gerais (UFMG) - a programme was set up in 1983 to carry out surveys of the fauna and vegetation of the reserve and of the lion tamarins in the inundation area, and rescue the groups of tamarins during the cutting of the forest prior to the closure of the dam in 1986 (Mittermeier et al., 1985; Valle and Rylands, 1986). The operation was led by Célio Valle (UFMG) and Claudio Valladares-Pádua (CPRJ), and later on by Cory $T$. de Carvalho (IF/SP). Eight groups were located within the inundation area. One group of six was sent to CPRJ in November 1985 to supplement the breeding colony, and six males and eight females were transferred to the São Paulo Zoo in November 1986 , forming the basis for the current captivebreeding programme (Simon, 1988; Valladares-Pádua and Mamede, 1996). The Rosana dam was closed in October 1986 and the area of the Morro do Diabo State Reserve was reduced to 34,441 ha. The reserve, which had benefited from considerable investment by CESP, was changed to a State Park in July 1986.

The census of groups affected by the dam and a study on a radio-collared group in 
Morro do Diabo provided the first field data for the species since Coimbra-Filho's (1970, 1976) observations in the 1970s (Carvalho et al., 1989; Carvalho and Carvalho, 1989). A long-term field study was also set up there by Valladares-Pádua (1993) in 1984, and included studies of the behaviour, ecology and genetics of wild groups, along with vegetation analyses (Valladares-Pádua, 1997). An environmental education programme specifically for the Morro do Diabo State Park was established in 1989 by Susana Pádua (Pádua and ValladaresPádua, 1997). Valladares-Pádua et al. (1994) estimated a population of 821 lion tamarins in the 23,800 ha of suitable habitat in the park. Although small, the Caetetus State Ecological Station is significant in being well to the east of Morro do Diabo State Park. ValladaresPádua et al. (1994) estimated a population of 69 lion tamarins in the 2000 ha of suitable habitat there.

With the loss of the majority of forests in the region, the species was thought for a number of years to be restricted to the two protected areas. However, further populations of black lion tamarins were discovered in the early 1990 s in five small forest patches on private lands (Valladares-Pádua et al., 1995). One of these was in the Fazenda Rio Claro in the municipality of Lençóis Paulista $\left(22^{\circ} 36^{\prime} \mathrm{S}\right.$, $\left.48^{\circ} 49^{\prime} W\right)$.

\section{The black lion tamarins at the Fazenda Rio Claro}

The black lion tamarins at the Fazenda Rio Claro inhabit gallery forests surrounded by Eucalyptus plantations (Figure 1). All the new populations described in the early part of this decade are very small, and one of the key aspects concerning their continued survival is the problem of inbreeding. The solution to this lies in the formulation of a metapopulation management plan involving intensive monitoring, reintroduction, translocation and the managed dispersal of individuals between the subpopulations, which includes the captive animals now maintained in 10 zoos and institutions in Brazil, USA, Europe and Australia
(Valladares-Pádua and Martins, 1996). One group of black lion tamarins has already been translocated successfully from the Fazenda Rio Claro to an unoccupied forest fragment in the Fazenda Mosquito in the region of Pontal and is doing extremely well. Research aimed particularly at studying the effects of fragmentation on genetic variability in the various isolated populations will provide important support for their management, as well as an understanding of the role of their reproductive strategies and dispersal patterns. This is being carried out by Beatriz Perez-Sweeney and Don Melnick of the Center for Environmental Research and Conservation (CERC), University of Columbia, New York. It is hoped that the proposed metapopulation management plan will increase considerably the probability of the survival of these animals in the wild, minimizing the projected loss of genetic variability that occurs in isolated populations, while providing detailed censuses of their effective size (Seal et al., 1991; Valladares-Pádua, 1993).

Ecological research on the groups in the Fazenda Rio Claro was started in 1991, and is aimed specifically at providing an understanding of their demography, feeding behaviour (key resources) and habitat requirements. There are numerous forest fragments, all privately owned, in the Lençóis Paulista region and one of the first measures will involve censuses and surveys of the entire area. Satellite images and recent aerial photographs will be used to map the forests to be surveyed and examine their potential for the establishment of further populations through translocation and reintroduction.

An important feature of future management strategies will involve attempts to link the various fragments along the Rio Claro and Rio Palmital by forest corridors through reforestation with Eucalyptus, using long cutting cycles and selective thinning, thus permitting the development of a dense understorey as well as commercial use of the trees (Duraflora, 1990). This is not economically impossible because it represents a very small proportion of the plantations on the farm. The black lion tamarins and other mammals could use these 


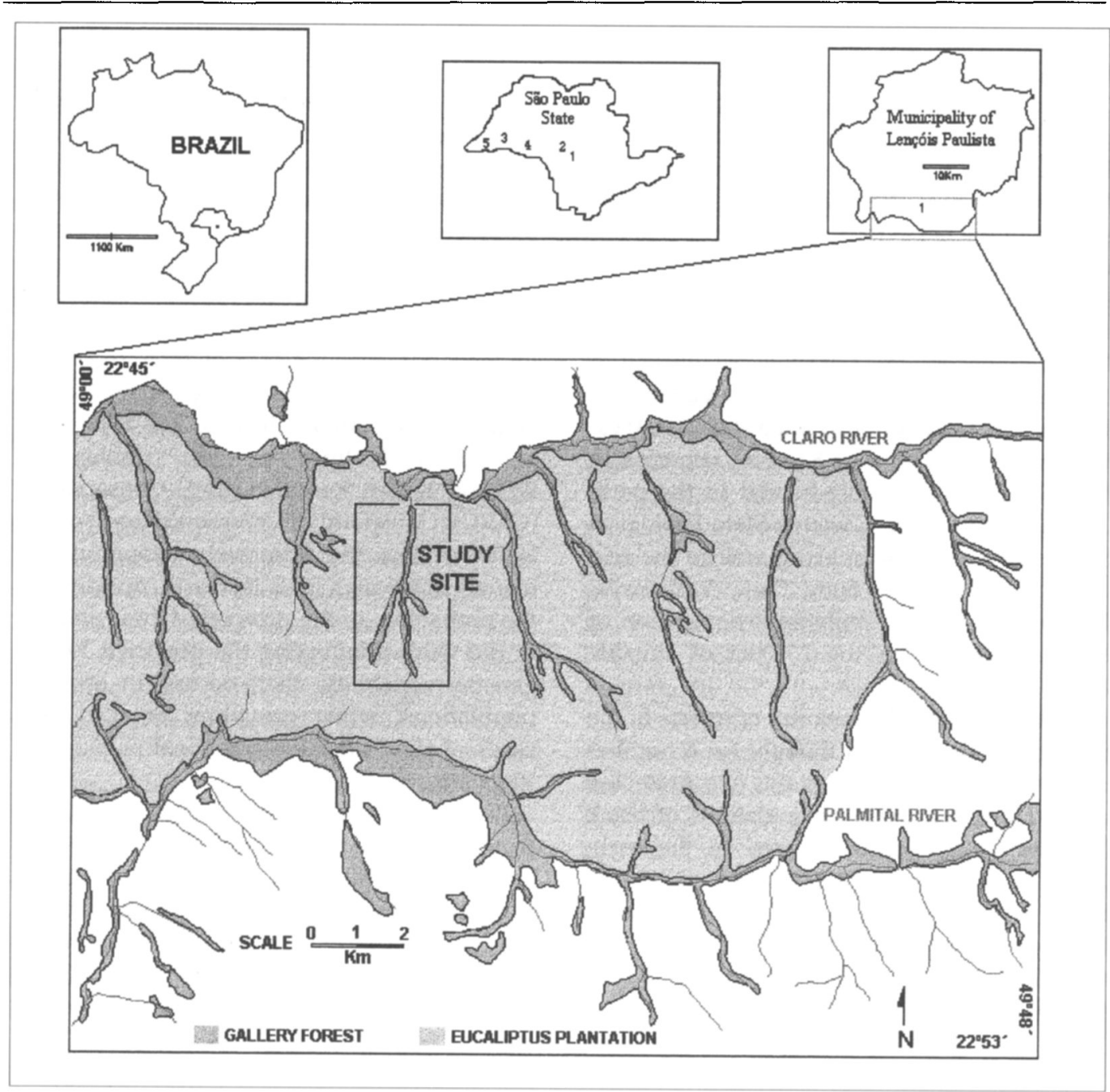

Figure 1. Map of the study area (Fazenda Rio Claro) showing gallery forest remnants, and showing positions of: 1, Fazenda Rio Claro in the municipailty of Lençóis Paulista; 2, Caetetus Ecological Station; 3, Morro do Diabo State Park; 4, Fazenda Mosquito; and 5, Reserva do Pontal.

areas for foraging and dispersal (MamedeCosta, 1997). In some areas it will also be necessary to increase the size of the existing gallery forest, reduced in places to narrow strips of trees only $10 \mathrm{~m}$ wide. Although feasible as corridors, the lion tamarins are highly susceptible to predation in these circumstances. The gallery forest could be extended by fencing-off the areas concerned and planting native species. Fire is a permanent hazard on the Rio Claro plantations, especially in the dry season, and is a risk to the native forests.
For this reason, the plantations should always be separated by firebreaks and kept at a certain minimal distance from the corridors of native forest.

The consistent use of tree hollows as sleeping sites is a unique characteristic of the genus Leontopithecus. Tree hollows are a key resource and their absence was believed to restrict the tamarins' use of secondary or early successional forest (Coimbra-Filho and Mittermeier, 1977; Rylands, 1989). In our studies at the Fazenda Rio Claro, however, tree hollows 
were scarce, and the tamarins use vine tangles instead, a more ephemeral resource than tree holes (Mamede-Costa, 1997). The placement of wooden (nesting) boxes of the appropriate size is being considered as an alternative. During the studies carried out on a group of eight black lion tamarins at Fazenda Rio Claro, we found that the few cavities $(n=10)$ used as shelters were, on average, $21 \mathrm{~cm}$ in diameter and $44 \mathrm{~cm}$ deep, and were situated at a mean height of $7.5 \mathrm{~m}$ above the ground. If tested and successful, nesting boxes could provide an important means of increasing the carrying capacity of the forest and reducing predation (Mamede-Costa, 1997).

An understanding of the population dynamics of the lion tamarins in these gallery forests is fundamental for the metapopulation management plan. Vital questions to be answered concern the patterns of dispersal and the social mechanisms involved, group structure, reproductive rate and infant survival, and an understanding of the opportunities, or lack of them, for dispersal in the various forest patches in the region. One simple, but effective, solution to connect forests separated by access roads has been the construction of a wooden pole bridge (Valladares-Pádua et al., 1995).

A question that continues to be controversial is how to reconcile conservation and regional development. Vital for the success of the Fazenda Rio Claro project and our efforts to conserve the lion tamarin groups of the region will be the collaboration and goodwill of the owners of the remaining forests. The provision of alternative economic activities, and clear demonstrations of the benefits of conserving gallery forest, and even increasing the area of forest cover in the region, is another major aspect, which is currently being addressed.

\section{Acknowledgements}

This study was supported by Duratex S.A. and the Brazilian Science Research Council (CNPq). We thank Anthony B. Rylands, Cláudio ValladaresPádua, Júlio $C$. Ribeiro and an anonymous referee for helpful criticism of an earlier text.

\section{References}

Carvalho, C.T. de and Carvalho, C.F. de. 1989. A organização social dos sauíspretos (Leontopithecus chrysopygus Mikan), na reserva em Teodoro Sampaio, São Paulo (Primates Callithricidae). Revista Brasileira de Zoologia, 6, 707-717.

Carvalho C.T. de, Albernaz, A.K.M. and de Lucca, C.A.T. 1989. Aspectos da bionomia do mico-leãopreto (Leontopithecus chrysopygus Mikan) (Mammalia, Callithricidae). Revista do Instituto Florestal, São Paulo, 1 (1), 67-83.

Coimbra-Filho, A.F. 1970. Acerca da redescoberta de Leontideus chrysopygus (Mikan, 1823) e apontamentos sobre sua ecologia. Revista Brasileira de Biologia, 30, 609-615.

Coimbra-Filho, A.F. 1976. Leontopithecus rosalia chrysopygus (Mikan, 1823), o mico-leão do Estado de São Paulo (Callitrichidae - Primates). Revista do Instituto Florestal, São Paulo, 10 (4), 1-36.

Coimbra-Filho, A.F. and Mittermeier, R.A. 1977. Conservation of the Brazilian lion tamarins (Leontopithecus rosalia). In Primate Conservation (eds H. S. H. Prince Rainier III of Monaco and G. H. Bourne), pp. 60-95. Academic Press, New York. Dean, W. 1995. With Broadax and Firebrand: The Destruction of the Brazilian Atlantic Forest. University of California Press, Berkeley.

Duraflora, 1990. Equipe técnica - Técnicas silviculturais objetivando minimizar impactos ambientais. In Congresso Florestal Brasileiro, (ed. Sociedade Brasileira de Silvicultura) pp. 98-100. Campos do Jordão, São Paulo.

IUCN, 1996. 1996 Red List of Threatened Animals. IUCN, Gland, Switzerland.

Leite, J.F. 1979. As Reservas Ecológicas do Sudeste Paulista. Paper presented at XXIII Congresso Estadual de Municípios, Praia Grande, São Paulo, May 1979.

Mamede-Costa, A.C. 1997. Ecologia de um grupo de micos-leões-pretos (Leontopithecus chrysopygus, Mikan, 1823) na mata ciliar da Fazenda Rio Claro, Lençóis Paulista, SP. MSc thesis, Universidade Estadual Paulista (UNESP), Rio Claro.

Mittermeier, R.A. 1982. Further Survey Work and Development of a Preliminary Management Plan for the Endangered Golden-rumped Lion Tamarin (Leontopithecus chrysopygus) in the Morro do Diabo State Reserve, São Paulo, Brazil. Atlantic Forest Region of Eastern Brazil-Project 12, IUCN/World Wildlife Fund.

Mittermeier, R.A., Pádua, C.V., Valle, C. and Coimbra-Filho, A.F. 1985. Major program underway to save the black lion tamarin in São Paulo, Brazil. Primate Conservation, 6, 19-21.

Pádua, S.M. and Valladares-Pádua, C. 1997. Um programa integrado para a conservação do micoleão-preto (Leontopithecus chrysopygus) - pesquisa, 
educação e envolvimento comunitário. In Educação Ambiental: Caminhos Trilhados no Brasil (eds S. M. Pádua and M. Tabanez), pp. 119-132. Fundo Nacional do MeioAmbiente, Instituto de Pesquisas Ecológicas, São Paulo.

Rylands, A.B. 1989. Sympatric Brazilian callitrichids: the black-tufted-ear marmoset, Callithrix kuhli, and the golden-headed lion tamarin, Leontopithecus chrysomelas. Journal of Human Evolution, 18, 679-695.

Seal, U.S., Ballou, J.D. and Valladares-Pádua, C. (eds). 1991. Leontopithecus: Population Viability Analysis Workshop Report. IUCN/SSC Captive Breeding Specialist Group (CBSG), Apple Valley, Minnesota.

Simon, F. 1988. Mico-leão Preto. Cadastro Provisório de Linhagens. Comitê Internacional de Preservação e Manejo, Fundação Parque Zoológico de São Paulo, São Paulo.

Valladares-Pádua, C. 1993. The ecology, behaviour and conservation of the black lion tamarin. PhD thesis, University of Florida, Gainesville.

Valladares-Pádua, C. 1997. Habitat analysis for the metapopulation conservation of black lion tamarins (Leontopithecus chrysopygus, Mikan, 1823). In A Primatologica no Brasil-6 (eds M. B. C. de Sousa and A. A. L. Menezes), pp. 13-26. Universidade Federal do Rio Grande do Norte, Sociedade Brasileira de Primatologia, Natal.

Valladares-Pádua, C. and Mamede, R. 1996. 1996
International Studbook Black Lion Tamarin Leontopithecus chrysopygus. International Committee for the Preservation and Management of the Black Lion Tamarin, São Paulo.

Valladares-Pádua, C. and Martins, C.S. 1996. Proposal for Conservation and Metapopulation Management of the Black Lion Tamarin (Leontopithecus chrysopygus). Instituto de Pesquisas Ecológicas, São Paulo.

Valladares-Pádua, C., Cullen, L. Jr and Pádua, S.M. 1995. A pole bridge to avoid primate kills. Neotropical Primates, 3 (1), 13-15.

Valladares-Pádua, C., Pádua, S.M. and Cullen, L. Jr. 1994. The conservation biology of the black lion tamarin, Leontopithecus chrysopygus: first ten years report. Neotropical Primates, 2 (suppl.), 36-39.

Valle, C. and Rylands, A.B. 1986. Lion tamarins rescued. Oryx $20,71-72$.

Ana Carolina Mamede-Costa, Departamento de Ecologia, Universidade Estadual Paulista (UNESP), 13506-900 Rio Claro, São Paulo, Brazil.

Nivar Gobbi, Centro de Estudos Ambientais, Universidade Estadual Paulista (UNESP), 13506-900 Rio Claro, São Paulo, Brazil.

Received 7 January 1998

Accepted 16 April 1998 